\title{
Incidence of Strict Quality Standards: Protection of Consumers or Windfall for Professionals?
}

Daiji Kawaguchi, Tetsushi Murao, and Ryo Kambayashi ${ }^{1}$

July 4, 2012

\footnotetext{
${ }^{1}$ Daiji Kawaguchi: Associate Professor, Faculty of Economics, Hitotsubashi University, Faculty Fellow, Research Institute of Economy, Trade and Industry, Research Fellow, Tokyo Center for Economic Research and Institute for the Study of Labor (IZA); Tetsushi Murao, Post-Doctoral Fellow, Institute of Innovation Research, Hitotsubashi University; Ryo Kambayashi: Associate Professor, Institute of Economic Research, Hitotsubashi University. This paper is a part of the project by the Ministry of Education, Culture, Sports, Science and Technology (Principal Investigator: Makoto Saito). Akiko Togawa provided excellent research assistance. We thank Makoto Saito, Kai-Wen Cheng, and the seminar participants at Hitotsubashi University, the Kansai Labor Economics Workshop, and National Taiwan University for their comments.
} 


\begin{abstract}
This paper examines the effects of upgrading product quality standards on product and professional labor-market equilibriums when both markets are regulated. The Japanese government revised the Building Standards Act in June 2007, requiring a stricter review process for admitting the plans of large-scale buildings. This regulatory change increased the wage of certified architects in Tokyo by $38 \%$ but did not increase their total hours worked because of an inelastic labor supply. The stricter quality standards created a quasi-rent for certified architects and owners of condominiums at a cost to consumers in the Tokyo area, who faced a 15\% higher condominium price after the policy change.
\end{abstract}

JEL Classification: J44 (Professional Labor Markets; Occupational Licensing)

Key Words: Labor Market of Professionals; Product Standard; Safety Regulation; Incidence of Government Regulation. 


\section{I . Introduction}

This paper examines the consequences of applying strict quality standards when only certified professionals are allowed to serve the market. Stricter regulations on the review process for plans of large-scale buildings, implemented in Japan from 2007, increased the wage of certified architects and the price of condominiums without increasing the architects' service input because of their inelastic labor supply.

When consumers cannot know a product's quality, governments often set the minimum quality standard for the product and restrict agents who can serve the market to resolve problems arising from information asymmetry (Hayne E. Leland, 1979, Carl Shapiro, 1986). Minimum quality standards in the output market and professional licensing in the input market often go hand-in-hand in government regulations. To list a few examples, aviation agencies set various safety standards for aircraft operation and allow only certified pilots to operate aircrafts. Health agencies set restaurants' hygiene standards and require restaurants to hire certified hygiene mangers. Accounting agencies set accounting rules and issue certificates for public accountants. Construction agencies set the safety standards for building structures and allow only certified architects to design the structures of large-scale buildings.

Although simultaneous regulations on both input and output markets are pervasive, our 
knowledge of the simultaneous responses of input and output markets to stricter product quality standards is limited, because most existing empirical studies assess the effect of product quality standards on product market outcomes (V. Joseph Hotz and Mo Xiao, 2005, Ginger Zhe Jin and Phillip Leslie, 2003) or the effect of professional regulations on labor-market outcomes (Mark A. Klee, 2010, Morris M. Kleiner and Alan B. Krueger, 2008, Mario Pagliero, 2011, J. Mark Ramseyer, 2009).

An exceptional study examines the effect of product regulations in the child-care industry on both product and labor markets and finds that stricter product regulations reduce the wage of nursery staff without affecting service price and quality (David M. Blau, 2007). This particular outcome is attributed to loose regulations regarding nursery staff's qualifications. If workers' qualifications are strictly regulated and their labor supply is inelastic, however, the incidence of higher quality standards may simply fall on qualified professionals as a quasi-rent. In a related context, previous studies show that the incidence of $R \& D$ or investment subsidy falls on scientists and engineers in the form of higher wage because of low substitutability for other inputs and an inelastic labor supply (Austan Goolsbee, 1998, Austin Goolsbee, 2003, Guntram B. Wolff and Volker Reinthaler, 2008).

An episode around a revision of the Building Standards Act of Japan in June 2007 sets 
a nice ground for examining the effects of stricter quality standards on both product and professional labor markets when both markets are regulated.

Hidetsugu Aneha, the first-class-certified architect of Japan, designed 20 condominiums and 1 hotel between 1997 and 2005. He was once a popular architect who designed "impossibly" low-cost condominiums with his "god hands." But his trick eventually turned out to be cheap. He faked structural calculations and reduced the number of steel rods within reinforced concrete down to the level that the designed structures did not achieve the seismic capacity required by the Building Standards Act (建築基準法) . By manipulating computer outputs of structural calculations, he deceived inspection agencies, but an architect who happened to come across the project blew the whistle and made Aneha's misconduct public. After thorough inspections by the government's regulatory body, the condominiums he had designed were revealed to not be able to withstand an earthquake of magnitude 6 . The regulatory body ordered demolishment of all the buildings. ${ }^{2}$

In response to harsh public criticism against the regulatory body, the government proposed revising the Building Standards Act, and the National Congress passed the revised Act. Implementation of the revised Building Standards Act in June 2007

\footnotetext{
${ }^{2}$ For details of the scandal, see the failure knowledge database by the Japan Science and Technology Agency written in the Japanese language. URL=http://shippai.jst.go.jp/fkd/Detail?fn=0\&id=CZ0200713
} 
required additional inspection procedures aimed to improve the quality of condominiums. This revision subsequently acted as a negative supply shock to the condominium market because of the shortage of certified architects who could legally conduct the intensified inspection procedure (Nikkei Architecture, September 10, 2007). Consequently, the construction of new condominiums plummeted, as shown in Figure 1, while the prices of used condominium skyrocketed, as shown in Figure 2. We take this event as a natural experiment to examine how the stricter product standards affected the respective equilibriums of the professional labor market and the product market.

To examine architects' labor-market responses, we rely on micro files of the Basic Survey of Wage Structure, conducted by the Ministry of Health, Welfare and Labor, between 1995 and 2008. Each year of surveys contains a sufficient number of certified first-class architects thanks to the survey's large sample size. This allows us to examine the change of wages and hours worked by architects before and after the implementation of new standards in June 2007. To preview our major results, the hours worked by architects were virtually irresponsive to the revision of the standards, but the monthly wage and annual bonus payment increased after June 2007. The combination of constant hours worked and increased compensation is consistent with the demand increase for architects, along with their inelastic labor supply. 
The increase of wages of certified architects resulted in an increase in the prices of condominiums transacted in the market. An analysis of all real-estate transaction records in the Tokyo metropolitan area between 2005 and 2010 reveals that the hedonic price index of condominiums relative to detached houses increased by 15 percent since the revision of the Act. The fraction of transactions involving newly constructed condominiums among all real-estate transactions did not increase from 2007 to 2010 , but the fraction of transactions involving used condominiums increased very sharply at the revision of the Act. The increase of the price and the constant quantity of new condominiums relative to detached houses suggest that the revision of the Act caused a demand shift, because consumers expected a limited supply of condominiums in the future. These findings lead us to conclude that the revision of Act created a quasi-rent for certified architects at the cost of consumers.

\section{II . Regulatory Institutions of Building Construction and Architects in Japan}

This section provides a brief overview of the regulation of building construction and the license regulation of certified architects in Japan. The Building Standards Act sets the minimum quality standard for all types of buildings. All construction plans should be reviewed and approved by the local government or a certified private inspection 
agency before its construction. Plans of buildings with a height of 13 meters or more, or non-wooden structures with a floor area of 300 square meters or larger, must be designed by certified first-class architects. Smaller buildings can be designed by second-class architects, wooden-structure architects, or anyone without certificates. Because of this regulation, the construction of almost every commercial building and condominium requires the involvement of first-class architects, while the construction of detached houses typically does not require such involvement.

The revision of the Building Standards Act in 2007 made the review process stricter for buildings with a height of 13 meters or more. The revised act practically required architects to use structural calculation software that was approved by the government and to submit original data so that the inspection agency could reproduce the results of structural calculations. Consequently, the construction of large-scale buildings came to require more labor input, including that of certified first-class architects, for drafting and reviewing the plans.

Certificates of all types of architects are issued by the Japan Architectural Education and Information Center, an organization of architects headed by an ex-bureaucrat of the Ministry of Land, Infrastructure, Transportation and Tourism. Other members of its executive board include architects and university professors in the field of architecture. 
The center gives examinations, which consist of academic and practical subjects, once a year. Only persons with a certain number of years of actual experience in the construction industry are allowed to take the examination. The requirement for years of experience depends on academic credentials; for example, 2 years of experience is required for 4-year college graduates who majored in architecture or civil engineering, while 4 years of experience is required for 2-year college or polytechnic graduates who majored in architecture or civil engineering. As these requirements indicate, academic credentials can be substituted by job experience. Indeed, among newly licensed first-class architects in 2010, whose average age was 32.2 , only $67.9 \%$ were 4-year-college graduates. ${ }^{3}$

Figure 3 provides a time series of passing rates of the license examination for first-class architects. Although the pass rates remained stable, around 12\%, until 2000, there was a big drop during 2001 to 2003 , down to $8 \%$. In the same period, the number of people who passed the examination dropped by half. Afterward, the pass rate fluctuated between 7 and 11\%. The reasons behind the drop and the fluctuations are unknown because the decision process of the passing rate is not made publicly available.

\footnotetext{
3 Web page of the Japan Architectural Education and Information Center, http://www.jaeic.or.jp/1k-data.htm, viewed on August 17, 2011.
} 
For the purpose of analyzing the effects of the Act's revision on the architect's market and the condominium market, we should note that the Act's revision increased the inelastic factor demand for first-class architects, who were indispensable for the construction of large-scale buildings, while the entry regulation of first-class architects made the supply of these buildings inelastic. The theoretical analysis in the next section incorporates these features of the markets.

\section{A Model of Product and Labor-Market Equilibriums}

The model introduced in this section illustrates how the revision of the Building Standards Act in June 2007 affects the equilibriums of the condominium and architect markets. In the analysis, the revision of the Act is modeled as a technology shock that lowers architects' labor productivity but potentially upgrades the quality of condominiums.

First, we assume that the quantity of condominiums, Q, is determined only by the labor input of the certified first-class architect, L. Although the construction of condominiums takes other inputs, such as unskilled labor and capital, we abstract these inputs away to focus only on the factor market of certified first-class architects. Abstracting these other factors does not affect the essence of our discussion, because the regulation prohibits the 
substitution of the first-class architect for other inputs. Assuming linear production technology with labor productivity parameter $\alpha$, the production function is given as:

$$
\mathrm{Q}=\alpha \mathrm{L}
$$

The marginal product of architect is $\alpha$. Thus, if condominium constructers are price takers and given a condominium price, $\mathrm{P}$, the labor demand function is given as:

$$
L(W, P)=\left\{\begin{array}{l}
0 \text { if } W>P \alpha \\
\infty \text { if } W<P \alpha
\end{array}\right.
$$

We assume that architects increase total hours worked as wage goes up along with the aggregate labor-supply function:

$$
\mathrm{L}^{\mathrm{S}}(\mathrm{W}) \text { and } \mathrm{dL}^{\mathrm{S}} / \mathrm{dW}>0 \text {. }
$$

The perfectly elastic labor-demand curve and the upward sloping labor-supply curve determine the labor-market equilibrium as: 


$$
\begin{gathered}
\mathrm{W}^{\mathrm{E}}=\mathrm{P} \alpha \\
\mathrm{L}^{\mathrm{E}}=\mathrm{L}^{\mathrm{S}}\left(\mathrm{W}^{\mathrm{E}}\right) .
\end{gathered}
$$

We now move to the analysis of the condominium market. Assuming that households have a quasi-linear utility function with respect to the discounted sum of service flow from a condominium with the quality $\theta$ and money, the aggregate demand function for the condominium is derived as:

$$
\mathrm{Q}^{\mathrm{D}}=\mathrm{Q}^{\mathrm{D}}(\mathrm{P}, \theta) \text { and } \frac{\partial \mathrm{Q}^{\mathrm{D}}}{\partial \mathrm{P}}<0, \frac{\partial \mathrm{Q}^{\mathrm{D}}}{\partial \theta}>0
$$

The quality of the condominium, $\theta$, potentially increases as the labor input per output increases, while the increase of the labor-input requirement is expressed as the reduction of $\alpha$ in our model. Thus, the quality of the condominium is determined as:

$$
\theta=\theta(\alpha) \text { and } d \theta / d \alpha \leq 0
$$

The production function posed at the beginning of this section constitutes the condominium-supply function: 


$$
\mathrm{Q}^{\mathrm{S}}=\alpha \mathrm{L}=\alpha \mathrm{L}^{\mathrm{S}}(\mathrm{P} \alpha)=\mathrm{Q}^{\mathrm{S}}(\mathrm{P})
$$

Given the labor-market equilibrium condition, the condominium market is at its equilibrium under the equilibrium price $\mathrm{P}^{\mathrm{E}}$ that is implicitly defined using the excess demand function as:

$$
\mathrm{F}\left(\mathrm{P}^{\mathrm{E}}\right)=\mathrm{Q}^{\mathrm{S}}\left(\mathrm{P}^{\mathrm{E}}\right)-\mathrm{Q}^{\mathrm{D}}\left(\mathrm{P}^{\mathrm{E}}\right)=\alpha \mathrm{L}^{\mathrm{S}}\left(\alpha \mathrm{P}^{\mathrm{E}}\right)-\mathrm{Q}^{\mathrm{D}}\left(\mathrm{P}^{\mathrm{E}}, \theta\right)=0 .
$$

Once the condominium's price is determined, the quantity of condominiums is determined. The architect labor-market equilibrium is also determined by $\mathrm{L}^{\mathrm{E}}=\mathrm{L}^{\mathrm{S}}\left(\alpha \mathrm{P}^{\mathrm{E}}\right)$ and $\mathrm{W}^{\mathrm{E}}=\alpha \mathrm{P}^{\mathrm{E}}$.

Our goal of the analysis is to examine how the architect's labor-market and the condominium's product-market equilibriums change in response to the revision of the Building Standards Act. The revision of the Act is modeled as an increase of the input requirement of architects per condominium, because the new procedure takes more architects' hours per condominium for inspection procedures. The effect of the change of $\alpha$ on condominium price $\mathrm{P}$ is calculated as: 


$$
\begin{aligned}
\left.\frac{\mathrm{dP}}{\mathrm{d} \alpha}\right|_{\mathrm{F}=0}= & -\frac{\partial \mathrm{F} / \partial \alpha}{\partial \mathrm{F} / \partial \mathrm{P}}=-\frac{\left(\mathrm{L}(\mathrm{W})+\mathrm{WL}^{\prime}(\mathrm{W})\right)-\frac{\partial \mathrm{Q}^{\mathrm{D}}(\mathrm{P}, \theta)}{\partial \theta} \frac{\partial \theta}{\partial \alpha}}{\alpha^{2} \frac{\partial \mathrm{L}^{\mathrm{S}}(\mathrm{W})}{\partial \mathrm{W}}-\frac{\partial \mathrm{Q}^{\mathrm{D}}(\mathrm{P}, \theta)}{\partial \mathrm{P}}} \\
& =-\frac{\left(\mathrm{L}(\mathrm{W})+\mathrm{WL}^{\prime}(\mathrm{W})\right)-Q_{\theta}^{D} \cdot \theta^{\prime}(\alpha)}{\alpha^{2} \mathrm{~L}^{\prime}(\mathrm{W})-Q_{P}^{D}}<0
\end{aligned}
$$

using an equilibrium condition $\alpha \mathrm{P}=\mathrm{W}$. Thus the increase of the labor-input requirement per output increases the product price. This magnitude of the price increase becomes more significant when the labor supply is unresponsive to the wage change (i.e. $L^{\prime}(W)$ is small) or the condominium demand is unresponsive to the price change (i.e. $Q_{P}^{D}$ is small in its absolute value). This intuitive result tells us that when the architects' labor supply and the condominium demand are not responsive to the shock, the price change should be significant.

The effect of the input requirement on the product quantity is calculated as follows:

$$
\left.\frac{\mathrm{dQ}}{\mathrm{d} \alpha}\right|_{\mathrm{F}=0}=\left(\mathrm{L}(\mathrm{W})+\mathrm{WL}^{\prime}(\mathrm{W})\right)-Q_{\theta}^{D} \cdot \theta^{\prime}(\alpha)-\left.Q_{P}^{D} \frac{d P}{d \alpha}\right|_{F=0}
$$

The increase of the condominium price resulting from the shock per se reduces the equilibrium quantity of condominiums $\left(Q_{P}^{D} \cdot d P / d \alpha>0\right)$, but if the effect of the 
demand increase resulting from the quality improvement dominates $\left(\mathrm{Q}_{\theta}^{\mathrm{D}} \cdot \theta^{\prime}(\alpha)<0\right)$, the equilibrium quantity could increase. Overall, the effect of the increase of the input requirement per output on the product quantity is either positive or negative.

The negative labor-productivity shock propagates to the architects' labor market. Using the equilibrium condition, $\mathrm{W}=\alpha \mathrm{P}$, we obtain

$$
\frac{\partial \mathrm{W}}{\partial \alpha}=\mathrm{P}\left(1+\frac{\alpha}{\mathrm{P}} \frac{\partial \mathrm{P}}{\partial \alpha}\right)
$$

Therefore, if a one-percent reduction of labor productivity increases the condominium price by more than one percent, the sign of the above partial derivative is negative. This means that the reduction of labor productivity increases the architect's wage, if the condominium price is elastic to the productivity shock. The architect's quantity responds to this wage change along with the labor-supply curve.

To summarize the discussion above, stricter standards that require more architects increase the condominium price, but they increase or decrease the equilibrium quantity. With an inelastic supply of architects, stricter standards result in higher product price because of the rise in architects' wage. Thus, the architects' supply elasticity is key for the welfare evaluation of the policy change. Now, we empirically examine how 
architects' person-hours and wage actually reacted to the stricter standards.

\section{Effects on the Market Equilibrium of Certified First-Class Architects}

\section{A. Data and Descriptive Analysis}

We now attempt to estimate the effect of the revision of Building Standards Act on the labor-market equilibrium. Theoretical analysis in the previous section suggests that if the revision of the Act sufficiently increases the price of condominiums, the demand for architects, as well as the quantity measured in person-hours and wage, would increase along with the labor-supply curve. When the labor-supply curve of architects is elastic, the revision of the act would increase architects' person-hour, while the wage would not increase much. In contrast, if the labor-supply curve is inelastic, architects would enjoy quasi-rent in the form of higher wage and their person-hours would not change much.

To examine the change of hours worked and the wages of architects before and after the revision of the Building Standards Act in June 2007, we rely on micro data from the Basic Survey on Wage Structure (BSWS), compiled annually by the Japanese government between 1995 and 2008. This survey includes observations randomly chosen from almost all regions and industries, except for agriculture, in Japan. The annual number of observations is approximately 1.5 million workers from $60-70$ 
thousand establishments. The sample includes all establishments with 10 or more employees in both private and public sectors and all establishments that belong to private firms with 5 to 9 employees.

The establishments in the sample are randomly chosen in proportion to the size of prefectures, industries, and number of employees. The randomly selected establishments were asked to extract their workers' information from their payroll records. A person in charge of personnel matters in each establishment was asked to randomly choose a number of workers from its pool of employees based on the given instructions for random sampling, including the sampling probability, which depended on the establishment's size and industry. Occupation is recorded for each randomly sampled worker for specific occupations, and first-class architect has been included in these occupations since 1995. Because of the large sample size, each year includes between 430 and 1,000 architects, as reported in Table 1.

The BSWS records each worker's age, sex, educational attainment, full-time/part-time status, occupation, employment status defined by the labor contract period, and working days/hours, as well as the firm's attributes, including the number of permanent workers, firm size, industry, and location. Regarding wages, the individual data include the contracted hours of work and overtime hours between June 1 and June 30, and the total 
amount of payment for the corresponding period, including overtime pay and allowances, such as those for dependents and commuting costs. The data also include the total bonus payment between January 1 and December 31 of the previous year.

We pay particular attention to the monthly scheduled wage, bonus, contracted hours, overtime hours, and total hours worked in the following analysis. The survey weights provided in the BSWS enable us to recover the estimated number of architects and the total person-hours worked by architects. Table 1 reports a descriptive analysis of the BSWS data.

The average scheduled hours fluctuate between 170 and 175 in the sample period, except for 1995 and 2004. We observe neither a particular trend nor an increase after the revision of the Act, which took place in June 2007. Both the number of architects and the total hours worked increased slightly after 2007 , but the increases lie within the range of long-term fluctuation. Overall, hours worked by architects did not increase after the revision of the Building Standards Act in June 2007.

In contrast to the irresponsive hours, scheduled monthly salary sharply increased from 2007. It is also notable that the bonus amount paid in 2007 increased sharply. The combination of irresponsive hours and a sharp increase of compensation is consistent with the predicted market response to the positive demand shock when the labor supply 
of architects is inelastic.

\section{B. Identification Based on Heterogeneous Policy Impacts by Prefectures}

We now examine how the wage and quantity of certified first-class architects responded to the regulatory change of June 2007. As shown in the descriptive analysis in the previous section, architects' wage had a declining time trend until 2007. Huge budget cuts in public construction in the $2000 \mathrm{~s},{ }^{4}$ as well as other adverse macroeconomic conditions, may well have affected the time series of architects' wages and hours worked. Therefore, we need to control for an underlying macroeconomic trend for a credible causal inference, but a one-time, uniform regulatory change does not allow us to distinguish the policy effect from other macroeconomic effects.

To overcome this difficulty, we exploit the heterogeneous impacts of policy change across prefectures depending on popular residential types. Living in condominiums is more popular in densely populated areas than in sparsely populated ones, where living in detached houses is common. Figure 4 illustrates the fraction of condominiums of total housing units across 47 prefectures taken from the 2003 wave of the Housing and

\footnotetext{
${ }^{4}$ According to System of National Account by Cabinet Office, the annual amount for public fixed capital formation by central and local governments and public enterprise peaked at 42 trillion yen in 1995 and decreased to 19 trillion yen in 2010 .
} 
Land Survey, Bureau of Statistics, Ministry of Internal Affairs and Communications. Condominiums are more popular in urban areas, such as Tokyo prefecture or Osaka prefecture, than in rural areas, such as Akita prefecture or Shimane prefecture. For example, the percentage of condominium units to total housing units is 71.5 percent in Tokyo prefecture, while it is 16.5 percent in Akita prefecture, which is located in the northeast rural area of Japan.

The revision of the Building Standards Act had a significant impact on the construction of larger-scale buildings, including condominiums, while it had practically no impact on the construction of detached housing. Thus, the revision of the Building Standards Act should have a stronger impact on urban architects' labor market than on rural architects' labor market. Under an assumption that regional architects' labor markets are not perfectly integrated at the national level, the revision of the Act should increase urban architects' wage more than rural architects' wage. As the degree of labor-market integration increases, labor supply curve of each prefecture becomes flatter and the heterogeneity of wage responses decreases. Assuming macroeconomic shocks in 2007 and 2008 are identical across prefectures, the policy effects are identified off the regional heterogeneity of wage responses.

We examine whether the revision of the Building Standards Act had a more significant 
impact on architects' labor market in prefectures where the fraction of condominium units to total housing units is high than in prefectures with a lower fraction by estimating the following difference-in-differences model:

$$
\begin{aligned}
& y_{i j t}=\beta_{0}+\beta_{1} \text { condo share } 2003, j \\
& \times \text { after }_{t}+\beta_{2} \text { after }_{t}+\beta_{3} \text { condo share } \\
& 2003, j \\
& \times \text { time trend }+c_{j t}+u_{i j t},
\end{aligned}
$$

where $y_{i j t}$ are wages, hours, or an indicator of recent participation of individual $i$, in prefecture $\mathrm{j}$ in year $\mathrm{t}$. The variable "condo share" is the fraction of condominium units of the total housing units in year 2003 in prefecture j, taken from the 2003 wave of the Housing and Land Survey, Bureau of Statistics, Ministry of Internal Affairs and Communications, which is the most recent quinquennial survey before the 2007 revision of the building standards act. The dummy variable "after" takes the value of one in 2007 and after. Including the interaction term of "condo share" and time trend allows for the heterogeneous growth trend across regions. The model is estimated by OLS under an assumption that $\mathrm{E}\left(\mathrm{c}_{\mathrm{jt}}+\mathrm{u}_{\mathrm{ijt}} \mid\right.$ condo share $_{2003, \mathrm{j}}$, after $_{\mathrm{t}}$, time trend $)=0$ with prefecture-level clustering robust standard error to allow for serial correlation of $c_{j t}$ (Marianne Bertrand, Esther Duflo and Sendhil Mullainathan, 2004). 
The results of the estimations appear in Table 2. Column (1) tells us that the scheduled monthly salary increased after 2007 in prefectures where the share of condominiums is high. Since the condominium fraction differs by 0.45 between Akita and Tokyo, the estimated coefficient of 0.40 implies that the increase in salary after 2007 differs by 18 percentage points between the two prefectures. We find more significant results for the bonus amount, as indicated in Column (2). The difference between the two prefectures is as large as 60 percentage points. In contrast, the hours worked did not increase, even in prefectures with a high condominium fraction, as reported in Columns (3) to (5). Column (6) reports that new architects did not increase in 2007 and 2008, suggesting that the extensive margin of labor supply was effectively zero. Column (7) reports that the fraction of architects with at least a Bachelor's degree increased in 2007 and 2008 in condominium-concentrated areas, but the estimated effect is statistically insignificant at the 10 percent level.

The combination of a significant wage increase and almost stable person-hours worked by first-class architects in condominium-concentrated areas suggests that positive labor-demand shock for architects in these areas is almost fully absorbed by the wage increase of architects, because their labor supply is inelastic. After all, the revision of the Building Standards Act of June 2007 helped architects to earn quasi-rent. 
To gauge the size of the compensation increase, we take an architect working in Tokyo prefecture as an example. The fraction of condominiums in 2002 was 0.71 in Tokyo. Thus the monthly salary increased by about $27 \%(=100 *[\exp (0.40 * 0.71-0.04)-1]$, where 0.40 is $\widehat{\beta}_{1}$ and -0.04 is $\widehat{\beta}_{2}$ of the estimated equation), and the annual bonus increased by about $90 \%\left(=100 *[\exp (1.33 * 0.71-0.30)-1]\right.$, where 1.33 is $\widehat{\beta}_{1}$ and -0.30 is $\hat{\beta}_{2}$ of the estimated equation). Calculated from the descriptive statistics reported in Table 1, the bonus payment consists of about $18 \%$ of architects' total annual compensation. Thus, the annual compensation of first-class architects in Tokyo increased by about $38 \%$ after 2007. The corresponding figure for first-class architects in Akita increased by only $0.5 \%{ }^{5}$

\section{Placebo Experiment Using Professional Engineers}

While the regression model allows for a quadratic time trend multiplied by the condominium fraction in 2003, one might argue that the results in Table 2 simply pick up the heterogeneous time trend between urban and rural areas. If macroeconomic conditions were favorable in urban areas in 2007 and after, wages might have increased in urban areas despite the revision of the Building Standards Act. To address this

\footnotetext{
${ }^{5}$ Calculated as $100 *[0.82 *[\exp (0.40 * 0.16-0.04)-1]+0.18 *[\exp (1.33 * 0.16-0.30)-1]]$.
} 
reasonable concern, we run placebo regressions that use professional engineers as an analysis sample. These professional engineers roughly correspond to professional engineers in the US and the UK. They hold national certificates in a variety of fields, such as machinery engineering, electrical engineering, and civil engineering, and the majority of them have certificates in the fields of construction, civil engineering, and geotechnology, because the certificate is required for those acting as construction consultants for public procurements. $79 \%$ of professional engineers work for private companies including consulting firms, $12 \%$ work for governments, and the remaining $9 \%$ are self-employed. ${ }^{6}$ Professional engineers make a good comparison group because the majority of them are employed in the construction industry, but they are not allowed to draft and review large-scale building plans, which only certified first-class architects can do. Professional engineer has been included in the specified occupations in the Basic Survey of Wage Structure since 2005.

The regression results using professional engineers as the analysis sample appear in Table 3. Contrary to the results for certified architects, we do not observe an increase of compensation in the prefectures where condominiums are popular after 2007 (Columns

\footnotetext{
${ }^{6}$ The institution of professional engineers and basic statistics of professional engineers are available in the brochure by the Institute of Professional Engineers, Japan. http://www.engineer.or.jp/examination_center/pejseido_201204.pdf (Accessed on May 13, 2012)
} 
(1) and (2)). Overtime hours increased in condominium-dense prefectures after 2007, but total hours did not increase (Columns (3) - (5)). Neither the fraction of job changers nor the fraction of college-educated engineers changed in condominium-concentrated prefectures in 2007 and after. Moreover, none of the estimated coefficients is statistically significant. Overall, the labor-market equilibrium of professional engineers did not change in 2007 and after in urban areas. Therefore, the results obtained for certified architects are not the mere reflection of a heterogeneous business-cycle effect between urban and rural areas.

\section{Effects on the Condominium Market}

\section{A. Data}

The analysis in this section assesses the impact of the revision of the Building Standards Act of June 2007 on the housing market, using micro data obtained from the Land General Information System （土地総合情報システム） maintained by the Ministry of Land, Transportation, Infrastructure and Tourism （国土交通省）. The ministry sends a questionnaire to new owners of real estate after transactions are registered with the regional legal affairs bureau. The survey is sent to all new owners and asks the price, types of real estate, and characteristics of real estate. The survey 
started in 2005, covering only three metropolitan areas around Tokyo, Nagoya, and Osaka, and expanded its coverage to all areas in 2007. The most recent data used in this study are from the 3rd quarter of 2010. Because the data set is gigantic and data can be downloaded by time period and city, we downloaded the data from four prefectures (Tokyo, Kanagawa, Chiba, and Saitama) of the Tokyo metropolitan area. We extract the transaction data of detached houses and condominiums from the 3rd quarter of 2005 until the 3rd quarter of 2010. Observations of detached houses are used to form a control group. The analysis sample includes 198,748 observations.

The variables included in the analysis sample and descriptive statistics are reported in Table 4. The price per square meters of detached houses decreases by $39 \%$ after the first quarter of 2007 partly reflecting the global collapse of real estate prices triggered by subprime mortgage crisis started in the summer of 2007. On the contrary, the price of condominiums decreased only by $8 \%$ in the same period. Condominiums tend to be located closer to the nearest stations and the nearest stations are closer to Tokyo station. The condominiums are slightly older than detached houses.

\section{B. Hedonic Price Indexes of Condominiums and Detached Houses}

The sample contains a variety of residential units that differ in size, age, and location. 
To construct price indexes controlling for these characteristics, the hedonic model is estimated by regressing the natural log of price per square meter on a set of control variables and time dummy variables defined for each quarter of each year. The coefficients for time dummy variables, allowed to be different between condominiums and detached houses, are hedonic price indexes for each type of residence. The set of control variables include walking distance from the nearest train station measured in minutes, age of the structure, distance between the nearest train station and Tokyo station measured in minutes, and dummy variables for train lines. The train line in the Tokyo area virtually captures the quality of neighborhood. In addition, to capture the effect of location characteristics, such as the qualities of environment or public services, regional fixed effects are included. The unit of the fixed effects is city, and the analysis sample includes 243 cities. All coefficients, including coefficients for time dummy variables, are identified off the within-city variation and the time-series variation of explanatory variables.

The OLS estimation renders following result: 


$$
\begin{aligned}
& \log \left(\frac{\overline{\text { price }}}{\text { area }}\right)_{1 \mathrm{t} t}=-\begin{array}{c}
0.012 \\
(<0.000)
\end{array} \text { distance to station }{ }_{i}-\begin{array}{c}
0.021 \\
(<0.000)
\end{array} \text { age }_{i} \\
& -\underset{(<0.000)}{0.013} \text { distance to } \text { Tokyo }_{i}+\hat{d}_{\text {train line }}+\widehat{d}_{J} \\
& -\underset{(0.009)}{0.166} \text { used condo }_{i}+\underset{(0.018)}{0.128} \text { new } \text { condo }_{i}+\widehat{d_{t}}+\text { condo } \widehat{d_{t}} \\
& + \text { new condo } \widehat{d_{t}}, \quad N=198,748, \quad R^{2}=0.74 \text {, }
\end{aligned}
$$

where $\mathrm{i}$ is the index for an individual housing unit, $\mathrm{j}$ is the index for a city, and $\mathrm{t}$ is the index for a quarter of a year.

The coefficients for time dummy variables, setting the second quarter of 2007 as the reference group, are the hedonic price index for detached houses. Adding up coefficients for the time dummy variable and its interaction with the used condominium dummy variable for a specific period creates the hedonic price index for used condominiums. Similarly, adding an interaction term with new condominiums creates the index for new condominiums. Since the second quarter of 2007 is used as a reference group, the negative coefficient on the used condominium dummy variable implies that used condominiums were about $16.6 \%$ cheaper than comparable detached houses in the second quarter of 2007 . In contrast, new condominiums were $12.8 \%$ more expensive than comparable detached houses. Figure 5 reports the time series of hedonic price indexes for used and new condominiums and detached houses, which are normalized to 
zero in the second quarter of 2007.

The prices of both detached houses and condominiums fluctuated, reflecting the business cycle, but the price index of detached houses was generally higher than the price indexes of both new and used condominiums before the second quarter of 2007 when the standards became stricter. The price of used condominiums increased by about $7 \%$ toward the 2 nd quarter of 2008 , and after that, the price remained above the price of detached houses until the 3rd quarter of 2010. The price indexes of used condominiums and detached houses diverged by about $15 \%$ between the 2 nd quarter of 2007 and the 3rd quarter of 2010. The price indexes of used condominiums were statistically significantly lower before the revision of the Building Standards Act and significantly higher after the revision of the Building Standards Act than the price indexes of detached houses. This divergence of condominium prices from detached house prices implies that consumers in Tokyo were faced with 15\% higher used condominium prices after the revision of the Building Standards Act, and, as a result, owners of used condominiums received quasi rent.

The price index for new condominiums followed the price index of used condominiums until the $4^{\text {th }}$ quarter of 2008 , but it dropped from that time and almost converged with the price index of detached houses. Therefore, the strict standards 
decreased the supply of new condominiums and kept the price high for almost two years; eventually, though, the price fell more significantly than the price of used condominiums. The price indexes of new condominiums were not statistically different from the price indexes of detached houses after the revision of the Building Standards Act except during the $4^{\text {th }}$ quarter of 2008 and the $1^{\text {st }}$ quarter of 2009.

The price movement of new and used condominiums until the $4^{\text {th }}$ quarter of 2008 suggests that the two types of condominiums were substitutable and that the sudden drop of new construction of condominiums was partly absorbed by the transactions of used condominiums. Moreover, the fact that the price of new condominiums was close to the price of used condominiums after the regulation change implies that the revision of the Building Standards Act did not improve the quality of newly constructed condominiums, at least as perceived by consumers.

\section{Quantity Responses of New and Used Condominiums to the Revision of the Act}

The revision of the Building Standards Act in 2007 could have either increased or decreased the quantity of newly constructed condominiums. The revision may have decreased the supply because of the stricter plan-approval process, combined with the supply constraint of certified first-class architects. In contrast, it may have increased the 
demand for condominiums built after the revision of the Act, because the Act may have increased the average quality of condominiums in the market. Therefore, whether the revision of the Act increased or decreased the condominium quantity traded is ambiguous, as discussed in the comparative statistics in the theory section.

In addition to the positive demand shift because of possible quality improvement, consumers' expectation of a permanent supply decrease of condominiums because of stricter standards may have increased the current demand for condominiums. Although our limited knowledge of the demand and cost structures of the industry does not allow us to separate supply and demand effects, we assess which effect is empirically more relevant by examining how the quantity of newly constructed condominiums changed after the revision of the Act.

An immediate challenge for this empirical exercise is that the total amount of real-estate transactions is heavily affected by the macroeconomic business cycle. To control for these business-cycle effects, we use the fraction of the transactions of newly constructed condominiums among all housing transactions as the dependent variable, assuming that macroeconomic conditions affect the transactions of condominiums and detached houses equally.

The second challenge is the existence of the used condominium market. Among all 
transactions that involve condominiums in our analysis sample, $83 \%$ consists of transactions of used condominiums. The increase of condominium price may induce the transactions of used condominiums, given that brand-new and used condominiums are close substitutes. To address this possibility, we also examine the time series of the fraction of transactions of used condominiums among all real-estate transactions.

Transactions of new and used condominiums are tabulated in Table 5. The fraction of new condominiums dropped from $6.8 \%$ to $5.4 \%$ after the revision of the Act, while the fraction of used condominiums increased from $23.4 \%$ to $28.2 \%$. A quick glance at this table suggests that the revision of the Act reduced the supply of new condominiums and increased the demand for used condominiums.

To further examine the change in the relative quantity of newly constructed condominiums transacted relative to all real-estate transactions, holding location constant, the indicator of new condominiums is regressed on the distance to the nearest station, the distance to Tokyo, the train line, 243 city fixed effects, and quarter-year dummy variables, using the entire transaction record as the sample. The OLS estimation renders the following results. 


$$
\begin{aligned}
\text { newcondo }_{1 \mathrm{t}}= & \begin{array}{c}
-0.0007 \\
(<0.0000)
\end{array} \text { distance to station } \\
i & +\underset{(<0.000)}{-0.002} \text { distance to } \text { Tokyo }_{i} \\
& +\hat{d}_{\text {train line }}+\hat{d}_{\text {city }}+\widehat{d_{t}}, \quad N=198,748, R^{2}=0.11,
\end{aligned}
$$

where $\mathrm{j}$ is the index for a transaction, and $\mathrm{t}$ is the index for a quarter in a year. The negative coefficient on the distances to the nearest station and Tokyo station implies that condominiums became less popular in suburban areas. Similarly, the indicator of used condominiums is regressed on the same set of explanatory variables to render:

$$
\begin{aligned}
& \text { use } \widehat{\text { con }} \mathrm{do}_{1 \mathrm{t}}=\begin{array}{c}
-0.003 \\
(<0.000)
\end{array} \text { distance to station }_{i}+\underset{(<0.000)}{-0.003} \text { distance to } \text { Tokyo }_{i} \\
& +\hat{d}_{\text {train line }}+\hat{d}_{\text {city }}+\widehat{d}_{t}, \quad N=198,748, R^{2}=0.26 \text {. }
\end{aligned}
$$

Coefficients for time dummy variables, $\widehat{\mathrm{d}}_{\mathrm{t}}$, are displayed in Figure 6 for both brand-new and used condominiums. This figure shows that the fraction of newly constructed condominiums among all the real-estate transactions did not change between 2005 and 2010. In contrast, the fraction of transactions of used condominiums among all the real-estate transactions sharply increased by about $15 \%$ from the $1^{\text {st }}$ quarter of 2007 to the $2^{\text {nd }}$ quarter of 2007 , exactly the same timing of the revision of the Act. 
The stable quantity of newly constructed condominiums may seem contradictory to the sharp dip in the number of ground-broken condominiums after June 2007, as reported in Figure 1, but the timings of construction and sale do not necessarily coincide if sellers of new condominiums adjust the timing of their sales. Developers that held new condominiums at the time of the revision of the Building Standards Act seem to have postponed the sales of these condominiums by a few months, expecting a supply shortage at that time. Also, since the number of ground-broken condominiums quickly recovered by early 2008, condominium developers may have shortened the time taken for construction. Combined with evidence of the increase of condominium prices after the revision of the Act, the stable condominium quantity implies that the supply of newly constructed condominiums is very inelastic, regardless of the fact that developers' adjustment of sale timing stabilized the transactions of newly constructed condominiums.

The increase of used condominium transactions by about 15 percentage points among all real-estate transactions is striking. This increase is larger than the unadjusted 4.8 percentage-point increase of the transactions of used condominiums before and after the revision of the Act, as reported in Table 5. This difference between the estimates implies that the revision of the Act increased the transactions of used condominiums in locations 
where transactions of used condominiums had not been active before the revision.

Increases of the prices and transactions of used condominiums imply that the demand for condominiums increased. This increase of the demand for condominiums cannot be explained by the increase of the average quality of condominiums resulting from the revision of the Building Standards Act, because used condominiums transacted in the 2nd quarter of 2007, at least, were constructed before stricter standards were applied. Most used condominiums transacted after the revision of the Act were also built before the revision.

The demand increase after the 2 nd quarter of 2007 is instead explained by consumers' expectation for the future contraction of the new condominium supply. The sharp dip in the number of ground-broken condominiums attracted media attention, because the slowdown of the construction of condominiums and commercial facilities was pointed out as the major cause of the slowdown of GDP growth in $2007 .^{7}$ This media coverage on the negative supply effect of the stricter standards made consumers expect a decrease of the condominium supply in the future and increased current demand for condominiums. This increase in the demand for condominiums raised the price for

\footnotetext{
${ }^{7}$ The Cabinet Office of the Japanese government expected the GDP growth of 2007 to be $2.0 \%$ at the beginning of the year but revised the estimated growth rate to be $1.3 \%$ by the end of the year. The Chief Cabinet Secretary, Nobutaka Machimura, at a press conference on December 19, 2007, admitted that the underperformance was explained mostly by the revision of the Building Standards Act.
} 
condominiums and the transactions of used condominiums, because the supply of used condominiums is more elastic than the supply of new ones.

Overall, condominium owners observed a price increase of used condominiums in 2007 and some of them sold their used condominiums, observing that the sale prices exceeded their reservation prices. Therefore, condominium owners in the second quarter of 2007 also received quasi-rent generated from the revision of the Building Standards Act.

\section{Conclusion and Implications}

The Japanese government implemented the revised Building Standards Act in June 2007. This reform requires a stricter review process exclusively applied for the plans of large-scale buildings and consequently increased the demand for certified architects for the construction of condominiums and commercial facilities.

This paper analyzed consequences of this legal change for product and labor markets. The results suggest that the revision of the Act increased the wage of certified first-class architects, though it did not increase their total hours worked because of their inelastic labor supply. Architects' increases of wage, not accompanied by increases in hours worked, were more pronounced in prefectures where the fractions of condominium units 
to total housing units were high. For instance, the mean annual earnings of architects in Tokyo prefecture increased about $38 \%$ after the revision of the Building Standards Act, while it was stable in Akita prefecture, which is a rural prefecture without many condominiums.

The stricter regulation, combined with the constancy of architects' labor input, reduced the construction of new condominiums and increased the price of condominiums. In the 3-year period between the 2nd quarter of 2007 and the 3 rd quarter of 2010 , the price index for used condominiums relative to the price index of detached houses increased by about $15 \%$. In response to this price increase, the fraction of used condominium transactions among all residential real-estate transactions increased by 15 percentage points. The combination of price increase and quantity increase of used condominiums implies that the revision of the Building Standards Act increased the demand for used condominiums. The consumers' expectation for the future contraction of the new condominium supply increased the demand for used condominiums in 2007 and after.

Overall, the introduction of stricter quality standards of the condominium market in 2007 created a quasi-rent for first-class architects and condominium owners by the second quarter of 2007 at a cost to new consumers in the form of higher condominium prices. 
For the purpose of increasing the number of high-quality condominiums in the market, the stricter standard should have been accompanied by a policy to increase the number of certified architects. Yet, as often observed in the phase of regulation tightening, the Japanese government introduced an additional regulation on architects' labor market by creating new professional certificates, first-class structure architects and first-class equipment architects, through revising the Architect Act. From May 2009, all buildings above a certain size are required to be reviewed by first-class structure architects. ${ }^{8}$ This revision might have decreased the supply of qualified architects even further. Instead of requiring stricter qualifications for professionals, the government should redesign the licensing and training system to increase the supply of qualified architects to match the increased demand.

This paper adds knowledge to the literature by examining the effects of the minimum quality standard on the product and professional labor markets when only certified professionals are allowed to serve the market. Lessons from the condominium's and architect's markets in Tokyo around 2007 tell us that regulators need to adjust policies on the two markets simultaneously to attain the desired policy goal. This lesson may

\footnotetext{
${ }^{8}$ Wooden structures with a height of 13 meters or higher, steel structures with 4 or more stories, reinforced concrete structures with the height of 30 meter or higher, and other structures specified by Cabinet Order must be reviewed by first-class structural architects.
} 
well be extended to other markets where both input and output markets are regulated.

The analysis in this paper was limited to examining the equilibrium price and quantity responses without referring to demand and supply structures. The estimation of demand and supply curves using richer information on consumer preferences and production costs are indispensable to fully assess the welfare and distributional impacts of the policy. This exercise is left for future work.

\section{References}

Bertrand, Marianne, Esther Duflo and Sendhil Mullainathan. 2004. "How Much Should We Trust Differences-In-Differences Estimates?" Quarterly Journal of Economics, 119(1), 249-75.

Blau, David M. 2007. "Unintended Consequences of Child Care Regulations." Labour Economics, 14(3), 513-38.

Goolsbee, Austin. 1998. "Does Government R \& D Policy Mainly Benefit Scientists and Engineers?" American Economic Review, 88(2), 298-302.

Goolsbee, Austin. 2003. "Investment Subsidies and Wages in Capital Goods Industries: To the Workers Go the Spoils?" National Tax Journal, 56(1), 153-65.

Hotz, V. Joseph and Mo Xiao. 2005. "The Impact of Regulations on the Supply and 
Quality of Care in Child Care Markets," NBER Working Paper No. 11873.

Jin, Ginger Zhe and Phillip Leslie. 2003. "The Effect of Information on Product Quality: Evidence from Restaurant Hygiene Grade Cards." Quarterly Journal of Economics, 118(2), 409-51.

Klee, Mark A. 2010. "How Do Professional Licensing Regulations Affect Practitioners? New Evidence," Mimeograph, Yale University.

Kleiner, Morris M. and Alan B. Krueger. 2008. "The Prevalence and Effects of Occupational Licensing," NBER Working Paper No. 14308.

Leland, Hayne E. 1979. "Quacks, Lemons, and Licensing: A Theory of Minimum Quality Standards." Journal of Political Economy, 87(6), 1328-46.

Pagliero, Mario. 2011. "What Is the Objective of Professional Licensing? Evidence from the Us Market for Lawyers." International Journal of Industrial Organization, 29(4), 473-83.

Ramseyer, J. Mark. 2009. "The Effect of Cost Suppression under Universal Health Insurance on the Allocation of Talent and the Development of Expertise: Cosmetic Surgery in Japan." Journal of Law and Economics, 52(3), 497-522.

Shapiro, Carl. 1986. "Investment, Moral Hazard, and Occupational Licensing." Review of Economics Studies, 53(5), 843-62. 
Wolff, Guntram B. and Volker Reinthaler. 2008. "The Effectiveness of Subsidies

Revisited: Accounting for Wage and Employment Effects in Business R\&D." Research Policy, 37(8), 1403-12. 
Table 1: Characteristics of First-Class Architects, Basic Survey of Wage Structure, 1995-2008

\begin{tabular}{ccccccccc}
\hline Year & $\begin{array}{c}\text { Number } \\
\text { of Obs }\end{array}$ & $\begin{array}{c}\text { Scheduled } \\
\text { Hours }\end{array}$ & $\begin{array}{c}\text { Overtime } \\
\text { Hours }\end{array}$ & $\begin{array}{c}\text { Total } \\
\text { Hours }\end{array}$ & $\begin{array}{c}\text { Monthly } \\
\text { Salary }\end{array}$ & $\begin{array}{c}\text { Annual } \\
\text { Bonus }\end{array}$ & Tenure & Age \\
\hline Total & 9,542 & 170.46 & 5.48 & 180.86 & 42.05 & 109.03 & 13.88 & 44.35 \\
& & $(22.38)$ & $(5.82)$ & $(29.09)$ & $(13.69)$ & $(100.36)$ & $(10.36)$ & $(9.91)$ \\
1995 & 430 & 180.79 & 8.31 & 189.10 & 40.58 & 148.75 & 12.63 & 41.47 \\
1996 & 578 & 170.91 & 10.63 & 181.54 & 45.67 & 164.92 & 13.64 & 42.36 \\
1997 & 565 & 169.32 & 9.55 & 178.87 & 44.44 & 139.31 & 13.83 & 41.83 \\
1998 & 689 & 170.37 & 6.34 & 176.71 & 42.49 & 136.32 & 13.27 & 45.04 \\
1999 & 711 & 171.04 & 7.65 & 178.69 & 46.16 & 122.14 & 15.95 & 44.79 \\
2000 & 731 & 172.30 & 9.03 & 181.33 & 43.25 & 103.89 & 15.43 & 44.64 \\
2001 & 706 & 175.28 & 9.65 & 184.94 & 42.13 & 92.41 & 14.08 & 43.80 \\
2002 & 713 & 172.27 & 7.16 & 179.43 & 41.07 & 87.77 & 14.50 & 44.06 \\
2003 & 737 & 174.43 & 12.75 & 187.17 & 41.52 & 76.32 & 13.12 & 43.56 \\
2004 & 726 & 166.55 & 9.03 & 175.57 & 40.82 & 67.27 & 14.50 & 46.57 \\
2005 & 1,000 & 169.49 & 11.48 & 180.97 & 37.57 & 64.33 & 12.53 & 44.58 \\
2006 & 719 & 173.16 & 8.01 & 181.17 & 36.25 & 76.23 & 12.63 & 45.91 \\
2007 & 604 & 172.72 & 11.58 & 184.31 & 41.85 & 109.76 & 14.95 & 47.17 \\
2008 & 652 & 167.04 & 10.87 & 177.92 & 43.43 & NA & 13.88 & 46.01 \\
\hline
\end{tabular}

Note: Annual bonus amount in the previous year is asked in the survey. Thus bonus amount in year 2008 is not available. 
Table 2: Effects of Stricter Regulation on Architects' Labor Market, 1995-2008

\begin{tabular}{lccccccc}
\hline & $(1)$ & $(2)$ & $(3)$ & $(4)$ & $(5)$ & $(6)$ & $(7)$ \\
\hline Dependent Variable & Ln & Ln & Ln & Ln & Ln & Ten $\leq 1$ & Educ=16 \\
& (salary) & (bonus) & $\begin{array}{c}\text { (scheduled } \\
\text { hour) }\end{array}$ & $\begin{array}{c}\text { (over } \\
\text { time) }\end{array}$ & $\begin{array}{c}\text { (total } \\
\text { hour) }\end{array}$ & & \\
Fraction of Condominiums in & 0.40 & 1.16 & -0.10 & 0.62 & -0.08 & -0.15 & 0.32 \\
$2002 * 2007-2008$ & $(0.12)$ & $(0.43)$ & $(0.05)$ & $(0.61)$ & $(0.11)$ & $(0.08)$ & $(0.21)$ \\
$2007-2008$ & -0.04 & -0.23 & 0.04 & -0.06 & 0.04 & 0.02 & -0.11 \\
& $(0.06)$ & $(0.19)$ & $(0.03)$ & $(0.25)$ & $(0.04)$ & $(0.04)$ & $(0.10)$ \\
Observations & 9,550 & 8,343 & 9,542 & 3,292 & 9,542 & 9,561 & 9,448 \\
R-squared & 0.07 & 0.11 & 0.03 & 0.02 & 0.01 & 0.02 & 0.03 \\
\hline
\end{tabular}

Notes: After dummy takes one in 2007 and 2008. Columns (1) to (5) reports OLS coefficients and columns (6) and (7) report marginal effects of Probit estimates evaluated at the sample mean. Standard errors robust against correlations within prefecture are reported in parenthesis. Pseudo R-squared are reported in columns (6) and (7). All specifications include the quadratic time trend and its interaction with the condominium fraction in 2002. The Fraction of condominiums in 2002 has the mean 0.32, the standard deviation 0.12, the minimum 0.16 (Akita) and the maximum 0.71 (Tokyo). 
Table 3: Effects of Stricter Regulation on Professional Engineers' Labor Market, 2005-2008

\begin{tabular}{lccccccc}
\hline & $(1)$ & $(2)$ & $(3)$ & $(4)$ & $(5)$ & $(6)$ & $(7)$ \\
\hline Dependent Variable & Ln & Ln & Ln & Ln & Ln & Ten $\leq 1$ & Educ=16 \\
& (salary) & (bonus) & $\begin{array}{c}\text { (scheduled } \\
\text { hour) }\end{array}$ & $\begin{array}{c}\text { (over } \\
\text { time) }\end{array}$ & $\begin{array}{c}\text { (total } \\
\text { hour) }\end{array}$ & & \\
Fraction of Condominiums in & -0.05 & 0.17 & -0.04 & 1.23 & 0.03 & -0.17 & -0.39 \\
$2002 * 2007-2008$ & $(0.45)$ & $(1.76)$ & $(0.13)$ & $(1.22)$ & $(0.15)$ & $(0.33)$ & $(0.45)$ \\
$2007-2008$ & 0.11 & -0.43 & 0.04 & -0.17 & 0.03 & 0.00 & 0.26 \\
& $(0.14)$ & $(0.62)$ & $(0.04)$ & $(0.39)$ & $(0.05)$ & $(0.10)$ & $(0.16)$ \\
Observations & 6,513 & 5,498 & 6,507 & 4,027 & 6,507 & 6,503 & 6,503 \\
R-squared & 0.03 & 0.03 & 0.02 & 0.01 & 0.01 & 0.01 & 0.02 \\
\hline
\end{tabular}

Notes: The same notes apply as in Table 2. 
Table 4: Characteristics of Transacted Real Estate, Tokyo Metropolitan Area, 2003 Q3 2010 Q3

\begin{tabular}{lccccc}
\hline Structure & Total & \multicolumn{2}{c}{ Detached Houses } & \multicolumn{2}{c}{ Condominiums } \\
\hline Period & Total & $-2007 \mathrm{Q} 1$ & $2007 \mathrm{Q} 2-$ & $-2007 \mathrm{Q} 1$ & $2007 \mathrm{Q} 2-$ \\
Price / Square Meter & 4,294 & 5,634 & 3,423 & 5,722 & 5,249 \\
(One Hundred Yen) & $(5,209)$ & $(8,311)$ & $(4,989)$ & $(3,772)$ & $(3,736)$ \\
Walking Distance to the Nearest Station & 16.2 & 15.8 & 19.8 & 8.8 & 10.4 \\
(Minutes) & $(15.9)$ & $(13.1)$ & $(18.1)$ & $(8.3)$ & $(10.2)$ \\
Age & 12.6 & 12.0 & 12.1 & 13.0 & 13.9 \\
& $(12.8)$ & $(13.8)$ & $(13.5)$ & $(11.2)$ & $(11.2)$ \\
Distance to Tokyo Station & 46.7 & 40.3 & 53.2 & 30.1 & 39.1 \\
(Minutes) & $(20.6)$ & $(14.2)$ & $(20.1)$ & $(13.0)$ & $(19.7)$ \\
$\mathrm{N}$ & 198,753 & 21,942 & 111,021 & 9,558 & 56,232 \\
\hline
\end{tabular}

Table 5: Transactions of New and Used Condominiums, Tokyo Metropolitan Area, 2003 Q3 - 2010Q3.

\begin{tabular}{lccc}
\hline & $-2007 \mathrm{Q} 1$ & $2007 \mathrm{Q} 2^{-}$ & Total \\
\hline New Condominiums (\%) & 6.8 & 5.4 & 5.7 \\
Used Condominiums (\%) & 23.4 & 28.2 & 27.5 \\
Detached Houses (\%) & 69.8 & 66.4 & 66.8 \\
Total Transactions & 31,500 & 167,253 & 198,753 \\
\hline
\end{tabular}


Figure 1: Number of Ground-Broken Condominiums and Detached Houses, April 2004 December 2008.

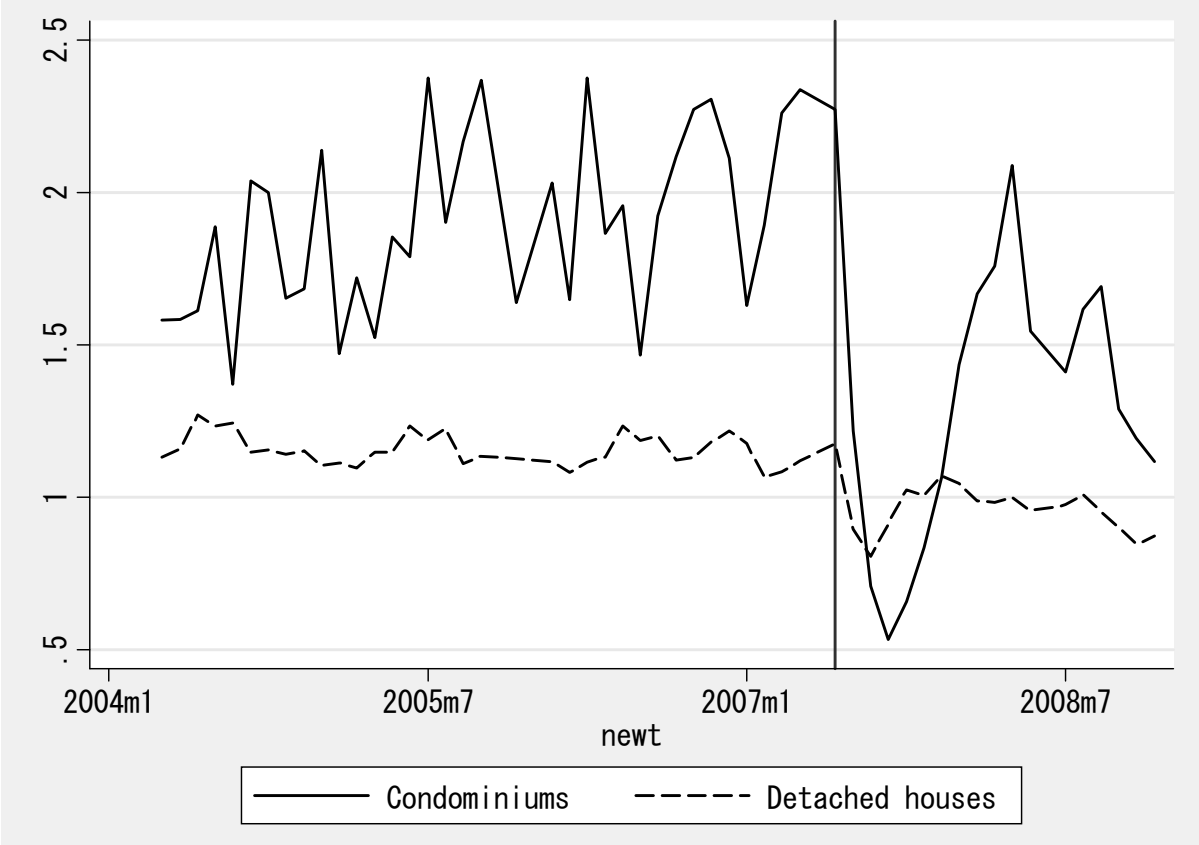

Note: Vertical line indicates June 2007.

Figure 2: Secondary Price of Condominiums, July 1997-December 2008

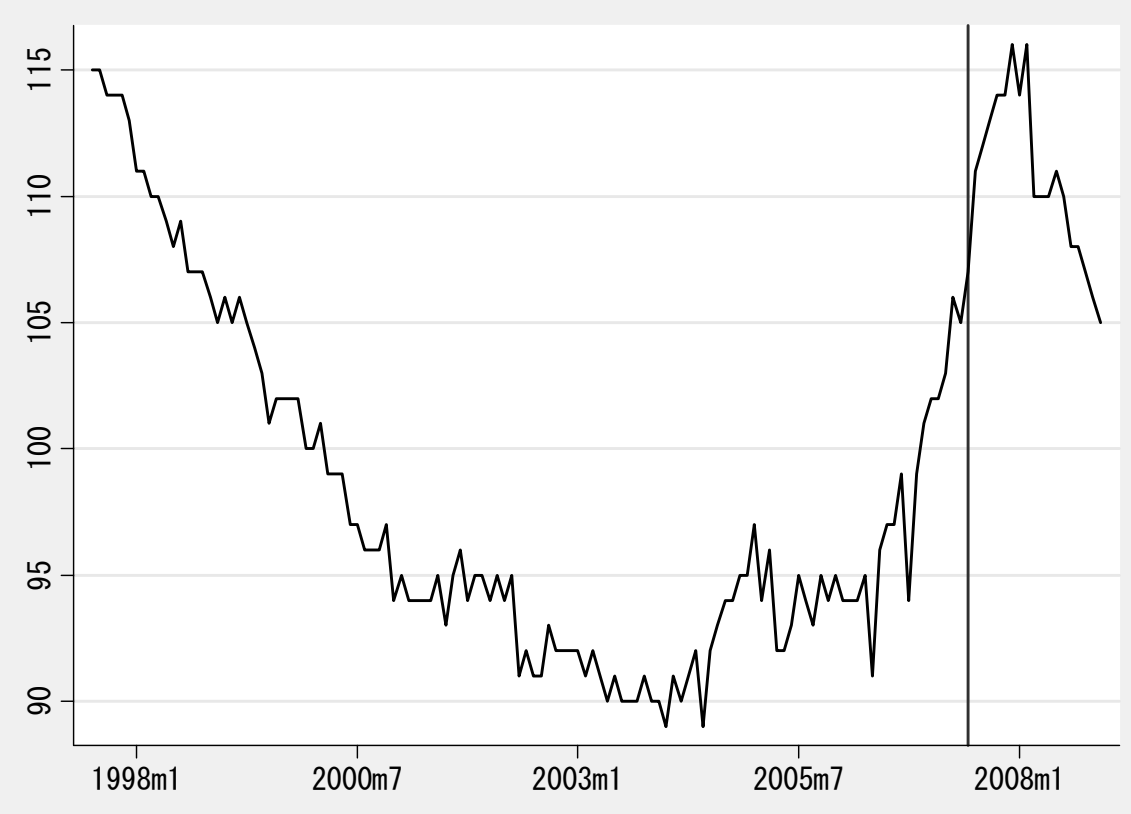

Note: Vertical line indicates June 2007. 


\section{Figure 3: Selectivity of Certification Examinations}

License Exams for First Class Architects

(1986-2008)

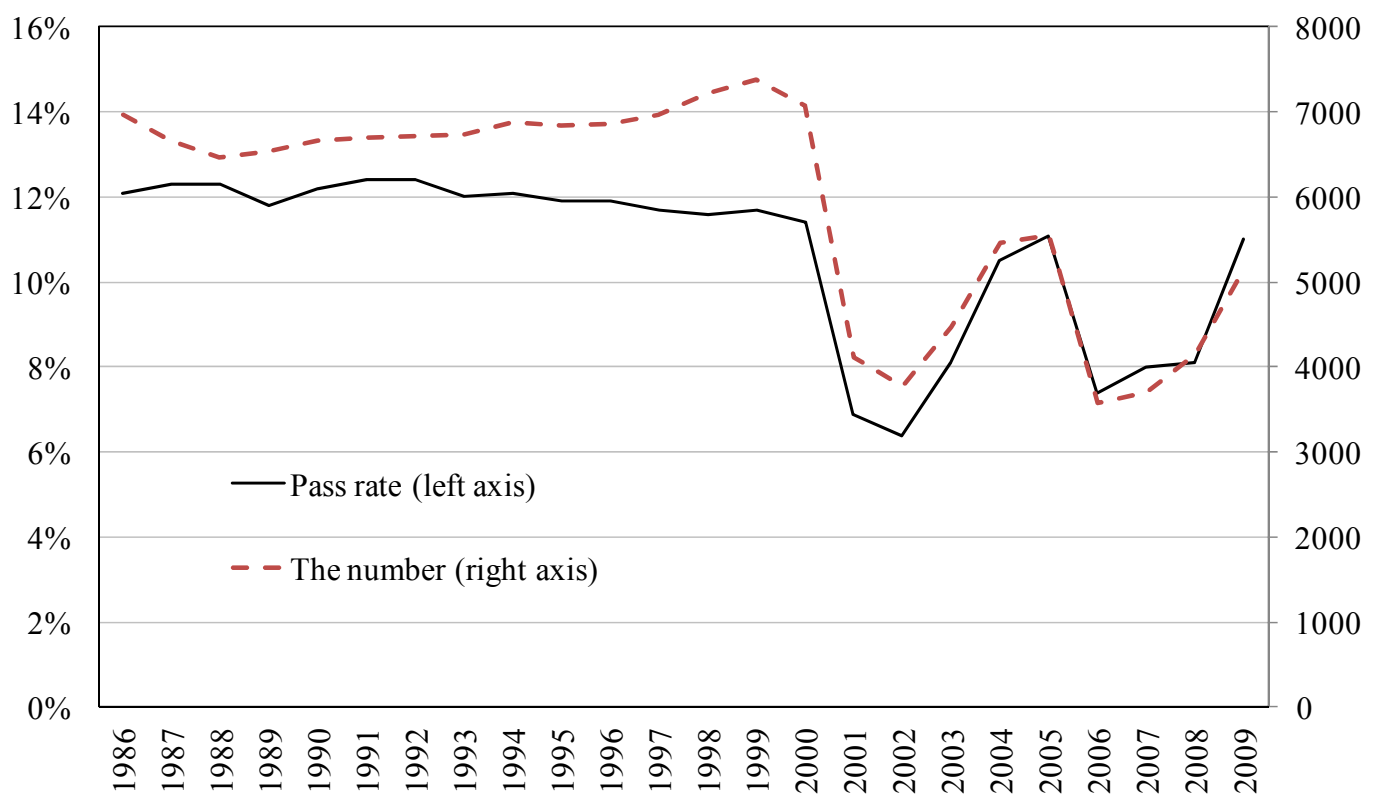


Figure 4: Percentage of Condominium Units to Total Housing Units

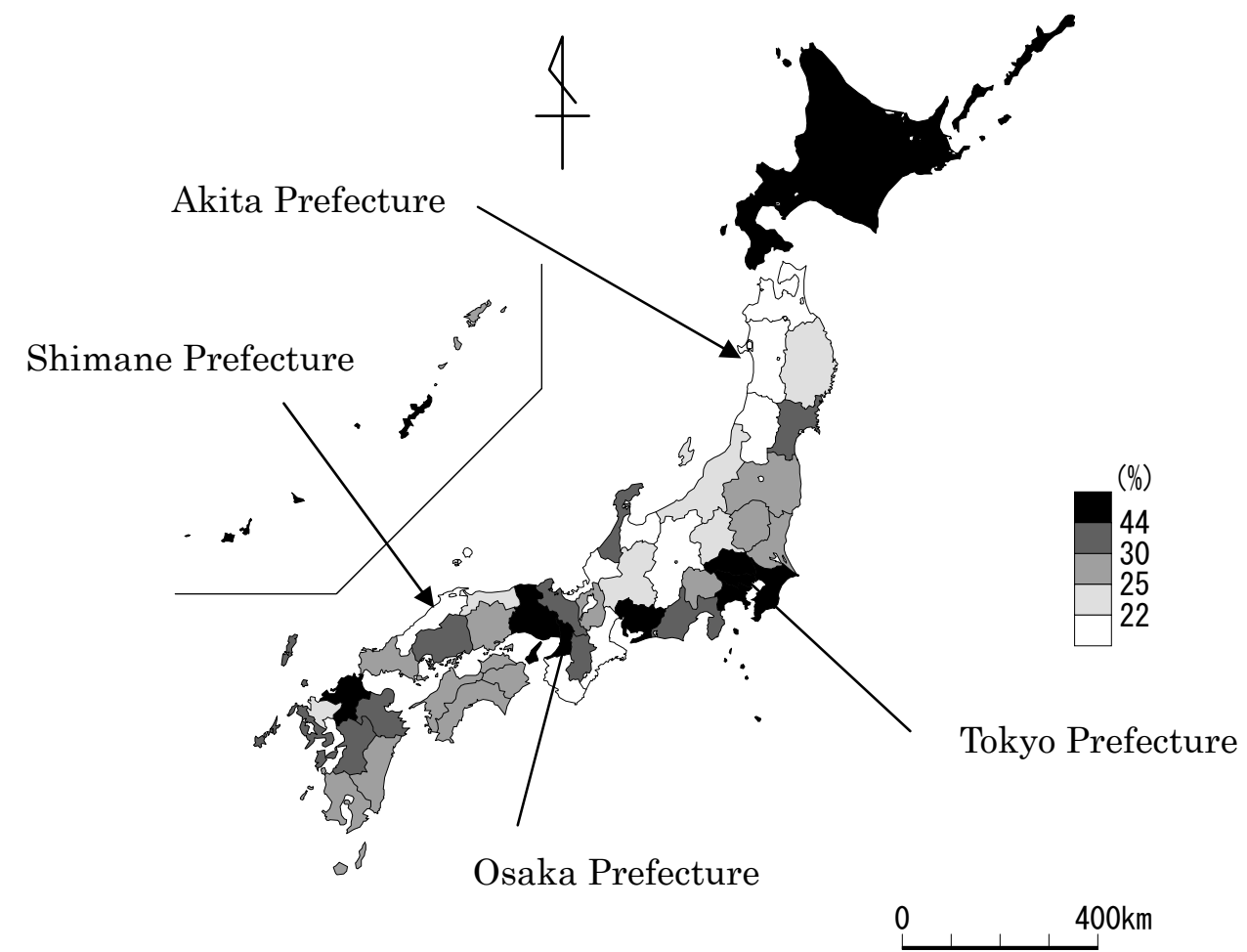

Source: 2003 wave of Housing and Land Survey, Bureau of Statistics, Ministry of Internal Affairs and Communications. The fraction has a mean 0.32, a standard deviation 0.12, a minimum 0.16 (Akita), and a maximum 0.71 (Tokyo). 
Figure 5: Hedonic Price Indexes of Condominiums and Detached Houses in Tokyo Metropolitan Area, 2005-2010, 243 City Fixed Effects Included.

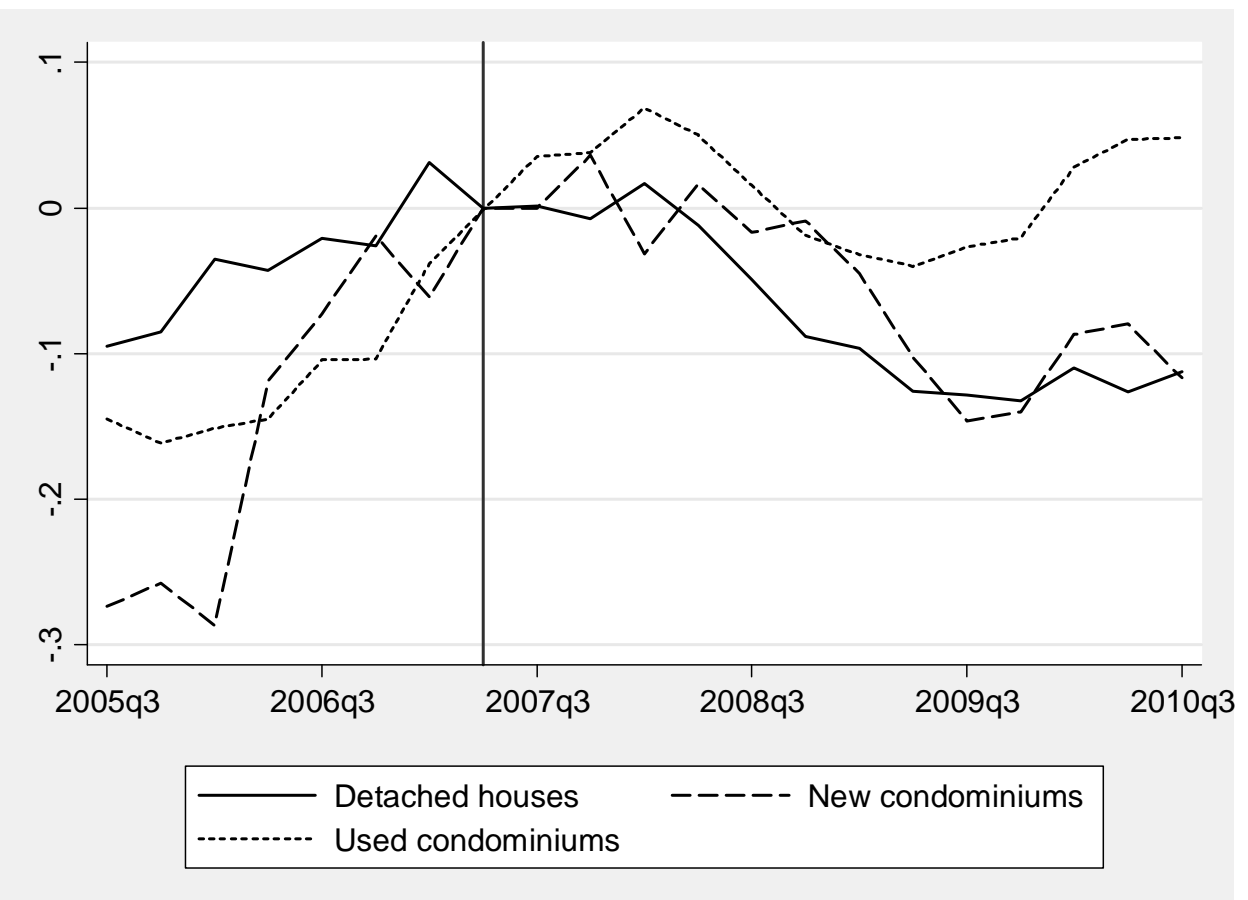

Figure 6: Fraction of Transactions of New and Used Condominiums among All Real Estate Transactions in Tokyo Metropolitan Area, 2005-2010. 243 City Fixed Effects Included.

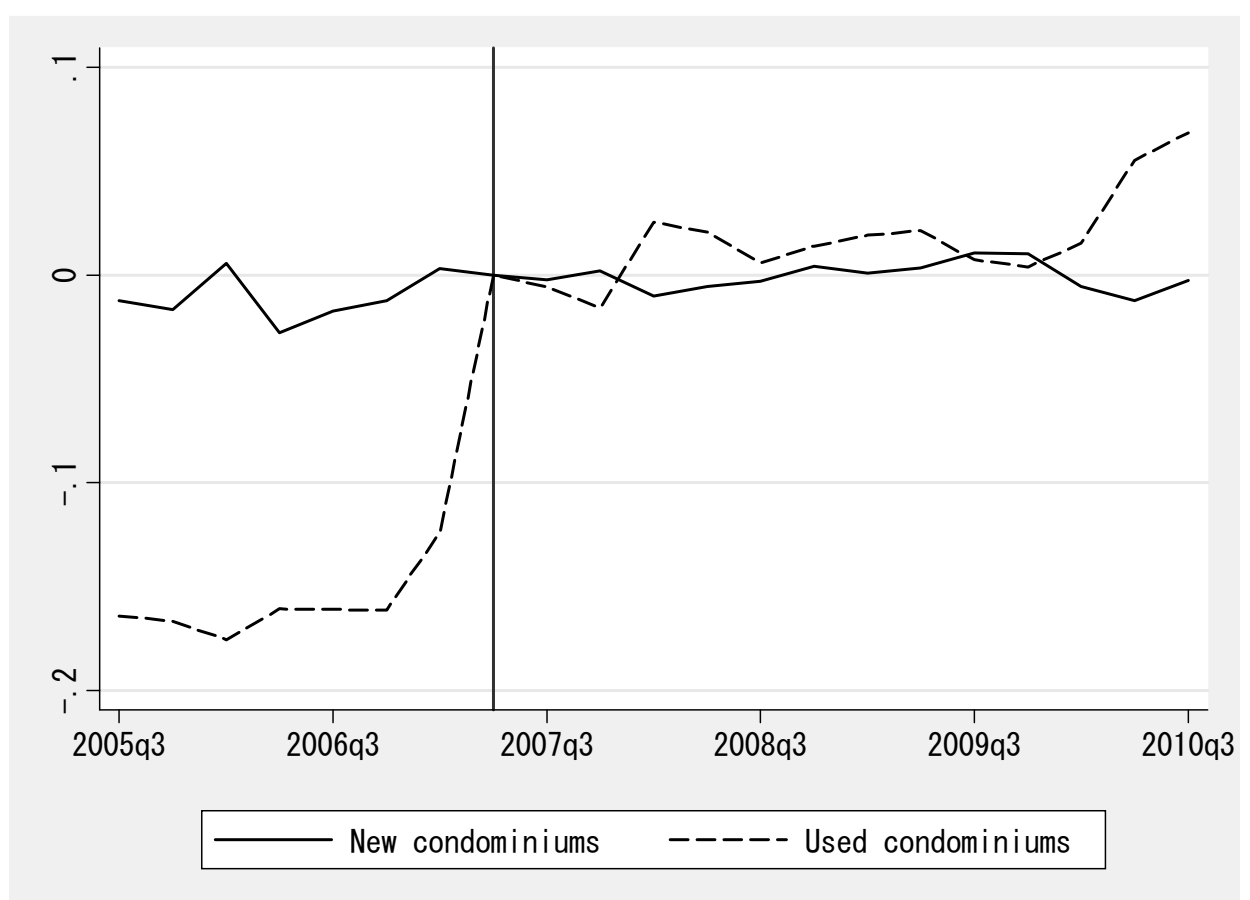

